\title{
CHEMICAL COMPOSITION AND CONTENT OF ESSENTIAL OIL FROM THE BUD OF CULTIVATED TURKISH CLOVE (Syzygium aromaticum L.)
}

\author{
M. Hakkı Alma, ${ }^{\mathrm{a}^{*}}$ Murat Ertaş, ${ }^{\mathrm{a}}$ Siegfrie Nitz, ${ }^{\mathrm{b}}$ and Hubert Kollmannsberger ${ }^{\mathrm{b}}$
}

\begin{abstract}
In this study, clove bud oil, which was cultivated in the Mediterranean region of Turkey, was provided from a private essential oil company in Turkey. Essential oil from clove (Syzygium aromaticum L.) was obtained from steam-distillation method, and its chemical composition was analyzed by GC and GC-MS. The results showed that the essential oils mainly contained about $87.00 \%$ eugenol, $8.01 \%$ eugenyl acetate and $3.56 \% \beta$-Caryophyllene. The chemical composition of the Turkish clove bud oil was comparable to those of trees naturally grown in their native regions.
\end{abstract}

Keywords: Syzygium aromaticum, Turkish Clove, Essential oil, Eugenol, Chemical composition

Contact information: a: Department of Industrial Engineering of Forest, University of Kahramanmaras Sutcu Imam, 46100 Kahramanmaras, Turkey; b: Lehrstuhl für Chemisch-Technische Analyse und Chemische Lebensmitteltechnologie, Technische Universität München, 85350 Freising-Weihenstephan, Germany; *Corresponding author: alma@ksu.edu.tr

\section{INTRODUCTION}

Essential oils of plants and their other products from secondary metabolism have had a great usage in folk medicine, food flavoring, fragrance, and pharmaceutical industries (Alma et al. 2004; Satil et al. 2003; Kusmenoglu et al. 1995; Digrak et al. 1999)

Cloves (Syzygium aromaticum L.) are the aromatic dried flower buds of a tree in the family Myrtaceae. The clove tree is an evergreen which grows to a height ranging from 10-20 m, having large oval leaves and crimson flowers in numerous groups of terminal clusters. The flower buds are at first of a pale color and gradually become green, after which they develop into a bright red, when they are ready for collecting. Cloves are harvested when 1.5-2 cm long, and consist of a long calyx, terminating in four spreading sepals, and four unopened petals which form a small ball in the centre (Kim et al. 1998).

Clove is native to Indonesia and used as a spice in virtually all of the world's cuisine. The name derives from French clou, a nail, as the buds vaguely resemble small irregular nails in shape. Cloves are harvested primarily in Indonesia and Madagascar; it is also grown in Zanzibar, India, Sri Lanka, and the "Spice Islands" (Moluccas, Indonesia known as the Bandas Islands). Cloves can be used in cooking, either whole or in a ground form, but as they are extremely strong, they are used sparingly. The spice is used throughout Europe and Asia and is smoked in cigarettes (also known as kreteks) in Indonesia and in occasional coffee bars in the West, mixed with marijuana to create marijuana spliffs. Cloves are also an important incense material in Chinese and Japanese culture. Clove essential oil is used in aromatherapy, and oil of cloves is widely used to treat toothache in dental emergencies (Kim et al. 1998).

It was reported that Syzygium aromaticum have been successfully used for asthma and various allergic disorders by oral administration (Kim et al. 1998). 
The essential oil of cloves has anesthetic and antimicrobial qualities and is sometimes used to eliminate bad breath or to ameliorate the pain of a bad tooth. Sesquiterpenes, found in clove, were investigated as potential anticarcinogenic agents (Zheng et al. 1992).

The whole essential oil or its main component eugenol $\left(\mathrm{C}_{10} \mathrm{H}_{12} \mathrm{O}_{2}\right.$; 4-allyl-2methoxy phenol), is used by dentists to calm the nerve inside a tooth after the removal of deep decay, and is the characteristic odor of a dentist's office. When mixed with zinc oxide, eugenol forms a cement used in dentistry (Lee and Shibamoto 2001). Clove oil is used in the traditional blend of choji (1\% clove oil in mineral oil) and is applied to Japanese sword blades to prevent tarnishing of the polished surface (Cai and Wu 1996; Baytop 1999). Also, eugenol derivatives or methoxyphenol derivatives in wider classification are used in perfumery and flavoring. They are used in formulating insect attractants and UV absorbers, analgesics, biocides and antiseptics. They are also used in manufacturing stabilizers and antioxidants for plastics and rubbers (Lee and Shibamoto 2001).

Three essential oils are available from clove species: clove bud oil, clove stem oil, and clove leaf oil. Each has different chemical composition and flavour. Clove bud oil, the most expensive and the best quality product, contains eugenol (80-90\%), eugenol acetate $(15 \%)$, and beta caryophyllene $(5-12 \%)$. It is well known that the amounts of secondary compounds like essential oils are affected by genetic factors, climate, soil and cultivation techniques (Pitarevic et al. 1985; Verzar-Petri et al. 1985; Arslan et al. 2004).

More recently, the clove species has been started to be cultivated in the Mediterranean part of Turkey. So far, no study has been done on the chemical composition of clove cultivated in Turkey. Therefore, in this study it was aimed at determining the chemical composition of the clove cultivated in Turkey.

\section{EXPERIMENTAL}

\section{Preparation of Essential Oil}

In this study, Clove bud essential oil was provided from a private plant (the socalled "OZDROG") in Hatay province, located in the southern of Turkey. The essential oil of clove, cultivated in Antalya province of Turkey, was obtained by a steamdistillation method by using an industrial type distiller for $3 \mathrm{~h}$. The essential oil was dried over anhydrous sodium sulfate $\left(\mathrm{Na}_{2} \mathrm{SO}_{4}\right)$ and stored at $-18{ }^{\circ} \mathrm{C}$.

\section{Chemical Analysis}

Qualification of the essential oil $(11.5 \mathrm{mg})$ diluted in diethyl ether $\left(\mathrm{Et}_{2} \mathrm{O}\right)(1 \mathrm{~mL})$ was analyzed on a Finnigan- MAT 8200 Mass Spectrometer coupled with a HewlettPackard GC- 5890II series GC by using An SE-54 fused silica capillary column (30 m x $0.25 \mathrm{~mm}$ i.d.; $0.25 \mu \mathrm{m}$ film thickness). Helium (He), having a flow rate of $1.15 \mathrm{~mL} / \mathrm{min}$, was used as carrier gas. The $\mathrm{GC}$ oven temperature was kept at $60{ }^{\circ} \mathrm{C}$ for $5 \mathrm{~min}$ and programmed to $260{ }^{\circ} \mathrm{C}$ at a rate of $2{ }^{\circ} \mathrm{C} / \mathrm{min}$ and then kept at $260{ }^{\circ} \mathrm{C}$. The injector temperature was $250{ }^{\circ} \mathrm{C}$. The amount of injection was $1 \mu \mathrm{L}$. The carrier gas was delivered at a constant pressure of $5 \mathrm{~kg} / \mathrm{cm}^{2}$. MS spectra were taken at El ion source of 70 $\mathrm{eV}$. The split ratio was 1:5. Retention indices for all the components were determined according to the Van Den Dool method (Dool and Kratz 1963), using n-alkanes as standard. Identification of the components was based on comparison of their mass spectra 
with those of internal (computer) library, NIST libraries and some reference compounds, and those described by Adams (1995).

Quantification of the essential oil was conducted by gas chromatography with a flame ionization detector (GC-FID) on a Hewlett-Packard GC-589011 series GC. A $1 \mu \mathrm{L}$ aliquot of oil was injected into the same column under the same GC conditions as described for the GC-MS study. However, the split ratio was 1:14.

\section{RESULTS AND DISCUSSION}

Table 1 represents the chemical composition of the essential oil from the bud of clove (Syzygium aromaticum). As can be seen from this table, 18 compounds, representing about $99.95 \%$ of the essential oil from clove, were characterized. The major components are as follows: eugenol $(87.00 \%)$, eugenyl acetate $(8.01 \%)$ and $\beta$ Caryophyllene (3.56\%).

A typical gas chromatogram of Turkish clove buds is shown in Fig. 1.

Table 1. Chemical Composition of the Essential Oil from Turkish Clove Buds

\begin{tabular}{lrrr}
\hline Compounds & $\mathrm{Rl}$ & $\%$ \\
\hline 2-Heptanone & 889 & 0.04 \\
$\alpha$-Pinene & 921 & 0.01 \\
$p$-Cymene & 1023 & $\mathrm{Tr}^{*}$ \\
Limonene+1,8 Cineole & 1029 & 0.01 \\
2-Heptyl acetate & 1046 & 0.04 \\
(E)- $\beta$-Ocimene & 1051 & 0.33 \\
2-Nonanone & 1092 & 0.02 \\
Linalool & 1098 & 0.01 \\
Methyl salicylate & 1189 & 0.07 \\
$p$-Allyl phenol & 1260 & 0.19 \\
Eugenol & 1361 & 87.00 \\
a-Copaene & 1372 & 0.10 \\
$\beta$-Caryophyllene & 1412 & 3.56 \\
$\alpha-H u m u l e n e$ & 1446 & 0.40 \\
$\Delta$-Cadinene & 1518 & 0.04 \\
Eugenyl acetate & 1526 & 8.01 \\
Caryophyllene oxide & 1573 & 0.10 \\
2(12),6(13)-Caryophyllen-dien-5-ol & 1627 & 0.02 \\
& & \\
${ }^{*}$ Tr < 0.01 & & \\
\hline
\end{tabular}




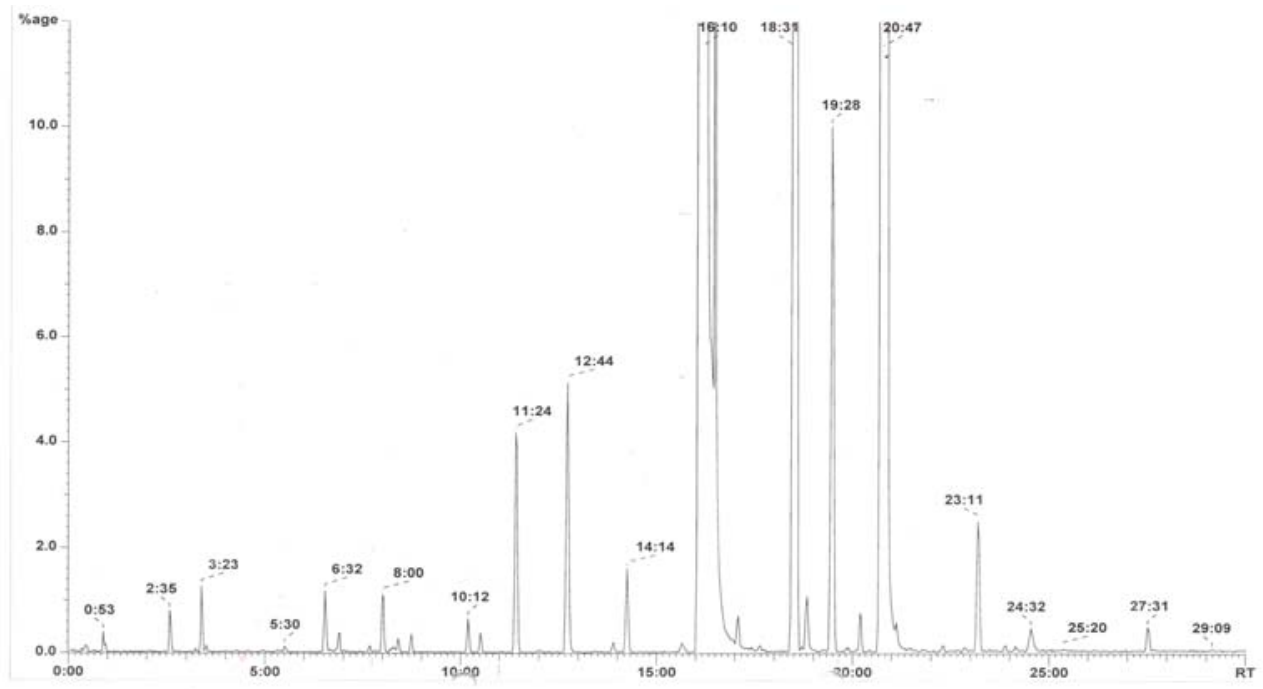

Fig. 1. Typical gas chromatogram of the essential oil from Turkish clove buds.

In previous studies, the essential oil contents of clove (Syzygium aromaticum) were reported by Tomaino et al. (2005); Lee and Shibamoto (2001) and Porta et al. (1998) as eugenol (82.6\%); eugenol (89.2\%), eugenyl acetate (8.6\%); and eugenol (77.4\%), eugenyl acetate (19.5\%) and caryophyllene (2.01\%), respectively. Our results were between the lowest and the highest values reported.

\section{CONCLUSIONS}

The chemical composition of clove bud oil provided from private Turkish company in Turkey was investigated. Essential oil from clove (Syzygium aromaticum L.), cultivated in the Mediterranean region of Turkey, was obtained from steamdistillation method, and its chemical composition was determined by GC and GC-MS. The findings indicated that the essential oils mainly had about $87.00 \%$ eugenol, $8.01 \%$ eugenyl acetate and 3.56\% $\beta$-Caryophyllene. The chemical composition of the Turkish clove bud oil was found to be comparable to those from clove trees naturally grown in its native regions.

\section{REFERENCES CITED}

Adams, R. (1995). Identification of Essential Oil Components by Gas

Chromatography/Mass Spectroscopy, Allured Publishing Co., Carol Stream, Illinois, USA.

Alma, M. H., Nitz, S., Kollmannsberger, H., Dığrak, M., Efe, F. T. and Yılmaz, N. (2004). "Chemical Composition and Antimicrobial activity of the essential oils from the gum of Turkish Pistachio (Pistacia vera L.)," J. Agric. Food Chem. 52, 39113914.

Arslan, N., Gürbüz, B. and Sarıhan, E. O. (2004). "Variation in essential oil content and composition in Turkish anise (Pimpinella anisum L.) populations," Turk. J. Agric. For. 28, 173-177. 
Baytop, T. (1999). "Therapy with medicinal plants in Turkey (Past and Present)," No. 3255, 2nd ed., Istanbul Publications of the Istanbul University, Istanbul.

Cai, L., and Wu, C. D. (1996). "Compounds from Syzygium aromaticum possessing growth inhibitory activity against oral pathogens," Journal of Natural Products. 59, 987-990.

Dığrak, M., Alma, M. H., and İlçim, A. (1999). "Antibacterial and antifungal effects of various commercial plant extracts," Pharm. Biol. 37, 216-220.

Dool, V. D., and Kratz, P. D. (1963). "A generalization of the retention index system including linear temperature programmed gas-liquid partition chromatography," $J$. Chromatogr. 11, 463-471.

Kim, H. M., Lee, E. H., Hong, S. H., Song, H. J., Shin, M. K., Kim, S. H., and Shin, T. Y. (1998). "Effect of Syzygium aromaticum extract on immediate hypersensitivity in rats," Journal of Ethnopharmacology 60, 125-131.

Kusmenoglu, S., Baser, K. H. C., and Ozek, T. (1995). "Constituents of the essential oil from the hulls of Pistacia vera L.," J. Essent. Oil Res. 7, 441-442.

Lee, K. G., and Shibamoto, T. (2001). "Antioxidant property of aroma extract isolated from clove buds [Syzygium aromaticum (L.) Merr. Et Perry]," Food Chemistry. 74, 443-448.

Pitarevic, I., Kustrak, D., Kuftinec, J., and Blazevic, N. (1985). "Influence of ecological factors on the content and composition of the essential oil in Salvia officinalis," In: Proceedings of the 15th International Symposium on Essential Oils, Svendsen, A. B. and Scheffer, J. J. C. (eds.). Martinus Nijhoff/Dr W. Junk Publishers, Boston, 199202.

Porta, G. D., Taddeo, R., D’Urso, E., and Reverchon, E. (1998). "Isolation of clove bud and star anise essential oil by supercritical $\mathrm{CO}_{2}$ extraction," Lebensm.-Wiss. u.Technol. 31, 454-460.

Satil, F., Azcan, N., and Baser, K. H. C. (2003). "Fatty acid composition of Pistachio nuts in Turkey," Chem. Nat. Comput. 39, 322-324.

Tomaino, A., Cimino, F., Zimbalatti, V., Venuti, V., Sulfaro, V., De Pasquale, A., and Saija, A. (2005). "Influence of heating on antioxidant activity and the chemical composition of some spice essential oils," Food Chemistry. 89, 549-554.

Verzar-Petri, G., Then, M., and Meszaros, S. (1985). "Formation of essential oil in clary sage under different conditions," In: Proceedings of the 15th International Symposium on Essential Oils, Svendsen, A. B. and Scheffer, J. J. C. (eds.). Martinus Nijhoff/Dr W. Junk Publishers, Boston, 19-21.

Zheng, G. Q., Kenny, P. M., and Lam, K. T. (1992). "Sesquiterpenes from clove (Eugenia caryophyllata) as potential anticarcinogenic agents," Journal of Natural Products 55, 999-1003.

Article submitted: January 16, 2007; First round of reviewing completed: February 12, 2007; Revised version received: May 17, 2007; Article accepted: May 17, 2007; Article published: May 23, 2007. 